\title{
Predators promote defence of rhizosphere bacterial populations by selective feeding on non-toxic cheaters
}

\author{
Alexandre Jousset ${ }^{1}$, Laurène Rochat ${ }^{2}$, Maria Péchy-Tarr ${ }^{2}$, Christoph $\mathrm{Keel}^{2}$, Stefan Scheu ${ }^{1,3,4}$ \\ and Michael Bonkowski ${ }^{1,3,5}$ \\ ${ }^{1}$ Institute of Zoology, Darmstadt University of Technology, Darmstadt, Germany and ${ }^{2}$ Département de \\ Microbiologie Fondamentale, Université de Lausanne, Lausanne, Switzerland
}

\begin{abstract}
Soil pseudomonads increase their competitiveness by producing toxic secondary metabolites, which inhibit competitors and repel predators. Toxin production is regulated by cell-cell signalling and efficiently protects the bacterial population. However, cell communication is unstable, and natural populations often contain signal blind mutants displaying an altered phenotype defective in exoproduct synthesis. Such mutants are weak competitors, and we hypothesized that their fitness depends on natural communities on the exoproducts of wild-type bacteria, especially defence toxins. We established mixed populations of wild-type and signal blind, non-toxic gacs-deficient mutants of Pseudomonas fluorescens CHAO in batch and rhizosphere systems. Bacteria were grazed by representatives of the most important bacterial predators in soil, nematodes (Caenorhabditis elegans) and protozoa (Acanthamoeba castellanii). The gacs mutants showed a negative frequency-dependent fitness and could reach up to one-third of the population, suggesting that they rely on the exoproducts of the wild-type bacteria. Both predators preferentially consumed the mutant strain, but populations with a low mutant load were resistant to predation, allowing the mutant to remain competitive at low relative density. The results suggest that signal blind Pseudomonas increase their fitness by exploiting the toxins produced by wild-type bacteria, and that predation promotes the production of bacterial defence compounds by selectively eliminating non-toxic mutants. Therefore, predators not only regulate population dynamics of soil bacteria but also structure the genetic and phenotypic constitution of bacterial communities.
\end{abstract}

The ISME Journal (2009) 3, 666-674; doi:10.1038/ismej.2009.26; published online 26 March 2009

Subject Category: microbial population and community ecology

Keywords: amoebae; cheating; nematodes; Pseudomonas fluorescens; protozoa; soil

\section{Introduction}

Fluorescent pseudomonads are ubiquitous rhizosphere bacteria, and many species produce toxic exoproducts that increase their resistance to microfaunal predators and improve their competitiveness against other bacteria (Jousset et al., 2008). These toxins often inhibit plant pathogens, making pseudomonads as potent biological control agents in agricultural systems (Haas and Defago, 2005). Toxin

Correspondence: A Jousset, Institute of Zoology, Darmstadt University of Technology, Schnittspahnstr. 3, D-64287 Darmstadt, Germany.

E-mail: alexandre.jousset@gmx.net

${ }^{3}$ These authors contributed equally to this study.

${ }^{4}$ Current address: Terrestrial Ecology and Rhizosphere Research, Institute of Zoology, University of Cologne, Weyertal 119, 50931 Köln, Germany

${ }^{5}$ Current address: JF Blumenbach Institute of Zoology and Anthropology, Georg August University of Göttingen, Berliner Street 28, 37073 Göttingen, Germany

Received 12 January 2009; revised 13 February 2009; accepted 17 February 2009; published online 26 March 2009 production in Pseudomonas is controlled at the post-transcriptional level by the gac/rsm cascade (Lapouge et al., 2008). Activation of the GacS/GacA two-component system by unknown signals leads to the production of small RNAs, which remove the translational inhibition of secondary metabolites. This cell-to-cell signalling allows the bacteria to coordinate their behaviour, activating the secondary metabolism at high bacterial density (Haas and Keel, 2003; Dubuis et al., 2007).

Pseudomonas fluorescens CHA0 is an effective colonizer of the rhizosphere of mono- and dicotyledonous plants possessing remarkable biocontrol efficiency (Voisard et al., 1994) and high resistance to predation (Jousset et al., 2006) due to the production of an array of secondary metabolites including toxins, such as hydrogen cyanide (HCN), 2,4-diacetylphloroglucinol (DAPG) and pyoluteorin (Haas et al., 2002).

Initially, rhizosphere bacteria originating from a single cell contribute equally to toxin production (de Werra et al., 2008), but cell signalling is 
genetically unstable, with gacS/gacA genes being frequently mutated and inactivated (MartinezGranero et al., 2005; van den Broek et al., 2005b). The resulting mutants are impaired in cooperative group traits, such as extracellular enzymes and toxin production (Lapouge et al., 2008), but under laboratory conditions show an improved growth rate compared to their wild-type ancestors due to the cessation of secondary metabolism (Bull et al., 2001). Despite being weak competitors when inoculated alone (Natsch et al., 1994), gacS/gacA mutants multiply rapidly within soil pseudomonad populations (Chancey et al., 2002; Sanchez-Contreras et al., 2002; Martinez-Granero et al., 2005). Consequently, we hypothesized that these mutants gain advantage by exploiting the exoproducts of the wild-type population, with their competitiveness being the highest at low frequency in a dense wild-type population (Velicer et al., 2000). In particular, mutants may benefit from the production of defence toxins that protect them from predators.

Predation significantly affects bacterial communities (Rønn et al., 2002; Blanc et al., 2006), and many bacteria evolved defence mechanisms such as the production of toxins. Toxic exoproducts protect bacteria by repelling predators, resulting in preyswitching towards more palatable prey (Jezbera et al., 2006; Liu et al., 2006), and at high toxin concentrations inhibit or even kill the predators (Matz et al., 2004). Predators, therefore, affect the fitness of bacteria at the individual level by selective feeding on non-toxic cells, and at the population level by preferentially consuming bacteria from populations that are little protected by toxins, that is, those containing few toxin-producing bacteria. Therefore, signal blind, non-toxic gacS/gacA mutants should be preferentially consumed by predators, resulting in a reduced fitness. Mutants in mixed populations neither contribute to autoinducer signals nor to toxin production (Dubuis and Haas, 2007), and high mutant load has been shown to reduce toxin-mediated biocontrol activity of P. fluorescens (Duffy and Defago, 2000). Consequently, increasing frequency of gacS/gacA mutants may result in a lower predation resistance of the whole population.

We established populations of $P$. fluorescens CHAO containing an increasing proportion of signal blind non-toxic gacS mutants in batch and rhizosphere systems. We exposed these populations to representatives of the two major groups of bacterial predators in soil, naked amoebae and nematodes, to investigate whether toxins differentially affect bacterial predators (Weitere et al., 2005). If gacS mutants exploit the exoproducts of the wild type, they should perform better at low density, and we tested whether this strain is subject to negative frequency-dependent selection. However, the lack of defence compounds should make bacteria vulnerable to predation, and we tested whether predators of different functional groups (amoebae and nema- todes) preferentially consume non-toxic mutants. As gacS mutants do not contribute to the defence of the population, we tested whether populations with higher loads of gacS mutants suffer from increased predation pressure by the different predators.

\section{Materials and methods}

\section{Organisms}

The wild-type strains P. fluorescens CHA0 (Voisard et al., 1994) and its isogenic gacS-deficient mutant CHA19 (Zuber et al., 2003) were tagged with two different fluorescent proteins allowing easy detection. A DsRed-tagged derivative CHA0- $r$ was constructed as follows: A 0.7-kb SmaI-HindIII fragment from pDsRed.T3_S4T, containing the dsred.T4_S4T gene, which encodes a rapidly maturing red fluorescent protein variant with strongly enhanced brightness (Sorensen et al., 2003), was cloned under the control of the constitutive $\mathrm{P}_{t a c}$ promoter in pME6552. A 1.5-kb MluI-HindIII fragment from the resulting plasmid carrying the $\mathrm{P}_{t a c}$-dsred.T3_S4T fusion was then cloned into the mini-Tn $7-\mathrm{Gm}$ carrier plasmid, pME3280b (Zuber et al., 2003). The construct obtained, pME7160, and the Tn7 transposition helper plasmid pUX-BF13 (Bao et al., 1991) were coelectroporated (Baehler et al., 2006) into the recipient strain CHA0. The gacS mutant CHA19 (Zuber et al., 2003) was tagged with a green fluorescent protein as follows: a mini-Tn7-gfp2 cassette carrying the gfpmut3 gene controlled by a modified $\mathrm{P}_{\text {tac }}$ promoter (Koch et al., 2001) was introduced into the chromosome of strain CHA19 using the transposition helper pUX-BF13, giving CHA19-g. The strains were kept routinely on nutrient agar plates (blood agar base $40 \mathrm{~g} \mathrm{l}^{-1}$, yeast extract $5 \mathrm{~g} \mathrm{l}^{-1}$ ) containing $8 \mu \mathrm{g} \mathrm{ml}^{-1}$ gentamycine sulphate (Sigma-Aldrich, Munich, Germany). Preliminary experiments under batch experiment conditions showed that labelling did not affect the growth characteristics of the two strains, and that no spontaneous gac mutants of the DsRed-tagged wildtype strain could be detected in mixed communities in the tested time frame (data not shown).

Before inoculation, bacteria were grown in nutrient broth-yeast extract (NBY) medium (nutrient broth $25 \mathrm{gl}^{-1}$, yeast extract $5 \mathrm{gl}^{-1}$ ) at $30^{\circ} \mathrm{C}$ with agitation. Late exponential phase bacteria were harvested by centrifugation (13000 r.p.m. for $2 \mathrm{~min}$ ), and washed three times in Neff's modified amoeba saline (AS; Page, 1988). The concentration of bacteria was determined by measuring optical density at $600 \mathrm{~nm}\left(\mathrm{OD}_{600}\right)$ and checked under an Axioscope 2 (Zeiss, Jena, Germany) epifluorescence microscope at $\times 400$ magnification.

The naked amoebae (Acanthamoeba castellanii) isolated from a woodland soil (Bonkowski and Brandt, 2002) were grown axenically on peptoneyeast extract-glucose (PYG) medium (peptone $20 \mathrm{gl}^{-1}$, yeast extract $5 \mathrm{gl}^{-1}$, glucose $\left.10 \mathrm{gl}^{-1}\right)$. Cells 
were harvested by centrifugation $(100 \mathrm{~g}, 10 \mathrm{~min})$ and washed twice in AS before inoculation.

The bacterivorous nematode Caenorhabditis elegans was grown axenically in liquid medium (peptone $30 \mathrm{gl}^{-1}$, yeast extract $30 \mathrm{~g} \mathrm{l}^{-1}$, haemoglobin $500 \mathrm{mg} \mathrm{l}^{-1}$ and cholesterol $1 \mathrm{mg} \mathrm{l}^{-1}$ ). Before inoculation, juveniles and adults were collected on a $5-\mu \mathrm{m}$ mesh, washed with sterile phosphate-buffered saline and resuspended in AS.

Experimental systems and setup

Two experimental systems of different complexity were established. In a simple batch system, the relative fitness of non-toxin-producing $P$. fluorescens mutant bacteria was investigated at six levels of mutant frequency. In complex rhizosphere systems, the fitness of wild-type and non-toxin-producing bacteria affected by both protozoan and nematode predators was investigated at three levels of mutant frequency.

Batch experiment. The experiment was set up in 96-well microtitre plates with mixed populations of $P$. fluorescens containing an initial frequency of 1 , 10, 33, 66, 90 and 99\% gacS mutants. Bacteria were inoculated at an initial concentration of $5 \times 10^{7} \mathrm{ml}^{-1}$ in AS containing $300 \mathrm{mg} \mathrm{l}^{-1}$ PYG medium, in the presence or absence of A. castellanii (5000 individuals per ml). Plates were grown at $22^{\circ} \mathrm{C}$ under agitation (150 r.p.m.). Preliminary experiments indicated no biofilm formation on the walls of the plate under the tested conditions (data not shown).

Rhizosphere experiment. The experiments were set up in microcosms filled with quartz sand and planted with rice. Quartz sand (grain size $100 \mu \mathrm{m}-$ $1.4 \mathrm{~mm})$ was dried $\left(72 \mathrm{~h}, 60^{\circ} \mathrm{C}\right)$ and rewetted with $10 \%(\mathrm{w} / \mathrm{w})$ of a modified Yoshida hydroponic nutrient solution ( $\mathrm{pH} \quad 6.0$ ) containing $1.43 \mathrm{mM}$ $\mathrm{NH}_{4} \mathrm{NO}_{3}, 0.37 \mathrm{mM} \mathrm{NaH}_{2} \mathrm{PO}_{4} \times 2 \mathrm{H}_{2} \mathrm{O}, 0.5 \mathrm{mM} \mathrm{K}_{2} \mathrm{SO}_{4}$, $1 \mathrm{mM} \mathrm{CaCl}_{2}$ and $1.6 \mathrm{mM} \mathrm{MgSO}_{4} \times 7 \mathrm{H}_{2} \mathrm{O}$ (Walia et al., 2005). The microcosms consisted of $30 \times 200 \mathrm{~mm}$ glass tubes (Schott, Mainz, Germany) filled with $50 \mathrm{~g}$ of the wet autoclaved sand $\left(30 \mathrm{~min}, 121^{\circ} \mathrm{C}\right)$.

Rice seeds (Oryza sativa cv. Zhonghua11) were dehusked by careful grinding with a pestle in a mortar, and surface sterilized by soaking in $96 \%$ ethanol for $1 \mathrm{~min}$ and for $30 \mathrm{~min}$ in a solution containing $30 \mathrm{gl}^{-1} \mathrm{NaCl}, 13 \mathrm{gl}^{-1} \mathrm{NaClO}, 1 \mathrm{gl}^{-1}$ $\mathrm{Na}_{2} \mathrm{CO}_{3}$ and $1.5 \mathrm{gl}^{-1} \mathrm{NaOH}$ (Hurek et al., 1994). Seeds were separately germinated in 96-wells microtitre plates containing $100 \mu \mathrm{l}$ AS. After 6 days, sterility was checked under a Diaphot inverted microscope (Nikon, Tokyo, Japan) at $\times 100$ magnification. Sterile seedlings were aseptically transferred to the microcosms, and the plants were grown at a constant temperature of $22{ }^{\circ} \mathrm{C}$ and a $16 \mathrm{~h}$ photoperiod $\left(500 \mu \mathrm{mol} \mathrm{s}^{-1} \mathrm{~m}^{-2}\right)$.

Three different mixtures of the bacterial strains P. fluorescens CHA0-r (wild type) and CHA19-g
(gacS mutant) were set up, with an initial frequency of $10 \%, 50 \%$ and $90 \%$ gacS mutants, and inoculated at a total concentration of $10^{6}$ bacteria per g sand (dry weight). Three predator treatments were established: a control without predators (Ctrl), addition of the bacterivorous amoeba $A$. castellanii (Amo) and addition of the bacterivorous nematode $C$. elegans (Nem). Amoebae were inoculated at a density of $10^{4} \mathrm{~g}^{-1}$ sand and nematodes at a density of $50 \mathrm{~g}^{-1}$ sand that correspond to their natural densities in the soil. Seven replicates were set up per treatment. Negative controls were consisted of non-inoculated sterile rice seedlings.

\section{Measurements}

In the batch experiment, $100 \mu \mathrm{l}$ aliquots were collected after $48 \mathrm{~h}$ and fixed in 3\% formaldehyde. The rhizosphere experiment was terminated after 12 days. Roots were removed from the sand, fixed in $8 \mathrm{ml}$ of ice-cold phosphate-buffered saline containing 3\% formaldehyde. Rhizosphere bacteria were detached by vortexing the roots for $2 \mathrm{~min}$, sonicating two times for $1 \mathrm{~min}$ and vortexing again for $2 \mathrm{~min}$.

To enumerate bacteria $100 \mu \mathrm{l}$ aliquots of bacterial suspensions were filtered on a $0.2 \mu \mathrm{m}$ polycarbonate membrane and counted under a Zeiss Axioscop 2 plus epifluorescence microscope at $\times 400$ magnification. The filter settings for green fluorescent protein and DsRed counts were, respectively, an excitation filter of 470 and $546 \mathrm{~nm}$, a dichroic filter of 493 and $580 \mathrm{~nm}$, and an emission filter of 505-530 and $590 \mathrm{~nm}$. Images were taken in triplicate using a Powershot G5 (Canon, Tokyo, Japan) digital camera, and bacteria were automatically counted using the ImageJ software (http://rsb.info.nih.gov/ij/). Red and green bacteria were counted separately. Unspecific excitation of the fluorescent proteins was assayed first with pure cultures of the two strains and did not interfere with the counts (data not shown).

Active nematodes were extracted in Baermann funnels, fixed in a $6 \%$ formaldehyde solution and enumerated at $\times 25$ magnification. Amoebae were enumerated at the end of the experiment using a modified most probable number method (Darbyshire et al., 1974). Briefly, $5 \mathrm{~g}$ of sand were gently shaken for $15 \mathrm{~min}$ in $20 \mathrm{ml} \mathrm{AS}$, and $100 \mu \mathrm{l}$ aliquots (four replicates per sample) were successively threefold diluted in a suspension of $10^{7}$ Escherichia coli per $\mathrm{ml}$ in AS in 96-well microtitre plates (Greiner Bio-one, Frickenhausen, Germany) and incubated in the dark at $15{ }^{\circ} \mathrm{C}$. Wells were checked for the presence of active and encysted amoebae after 3,7 and 14 days using an inverted microscope at $\times 100$ magnification.

\section{Statistical analyses and modelling of population dynamics}

The relative fitness $v$ of the gacS mutant was calculated by comparing its frequency at the 
beginning and end of the experiment as described by Ross-Gillespie et al. (2007):

$$
v=X_{2} \times\left(1-X_{1}\right) / X_{1} \times\left(1-X_{2}\right)
$$

with $X_{1}$, the initial and $X_{2}$, the final frequencies of the strain. The stable frequency of gacS mutants in the population was defined according to the regression slope as $v=1$.

The predation pressure $p$ on the roots was estimated as

$$
p=\left(Y_{\mathrm{C}}-Y_{\mathrm{p}}\right) / Y_{\mathrm{C}}
$$

where $Y_{\mathrm{c}}$ is the bacterial density in the control treatment, and $Y_{\mathrm{p}}$ is the bacterial density in the tested sample. The food selectivity index $s$ of predators was calculated by dividing the percentages of gacS mutants in the diet of the predators and in the population. These two proportions were defined as the contribution of the gacS mutants to the total predation pressure ponderated by the percentage of mutants in non-grazed populations

$$
s=\left(Z_{\mathrm{C}}-Z_{\mathrm{p}}\right) /\left(Y_{\mathrm{c}}-Y_{\mathrm{p}}\right) \times X_{\mathrm{C}}
$$

where $X_{\mathrm{c}}$ is the proportion of gacS mutants, and $Z_{\mathrm{p}}$ and $Z_{\mathrm{c}}$ are the total number of gacS mutants in the predator and control treatment, respectively. An index of 1 indicates the absence of preference for one of the two strains, an index $>1$ preference for the gacS mutant.

The relative fitness of the gacS mutant, the predation pressure and the predator selectivity were analysed with a general linar model (type III sum of squares) investigating the effect of predator treatment (factor) and the original mutant frequency (linear descriptor) in a full factorial design. Data were analysed using Statistica 7.0 (StatSoft Inc., Tulsa, OK, USA). Before statistical analyses, data were checked for homogeneity of variances and log transformed if necessary; percentage values were arcsin-square root transformed before analysis to meet assumptions of homoscedasticity.

\section{Results}

Fitness of the gacS mutant

The gacS-deficient mutant was subject to negative frequency-dependent selection both in batch and rhizosphere systems (Figures 1 and 2). Its relative fitness $(v)$ decreased in parallel with its frequency in the population, suggesting that the mutant was not able to displace wild-type populations, but instead required an elevated wild-type density for maximum fitness. In the batch system, pure cultures of gacS mutant grew better than the wild type in the exponential phase, but reached lower densities (see Supplementary Figure S1). In mixed cultures, the relative fitness of the mutant was negatively correlated with its initial frequency, showing a strong decline at high initial densities $\left(r^{2}=0.96, P<0.001\right.$; Figure 1). In absence of amoebae, the gacS mutant was fitter than the wild type at frequencies below

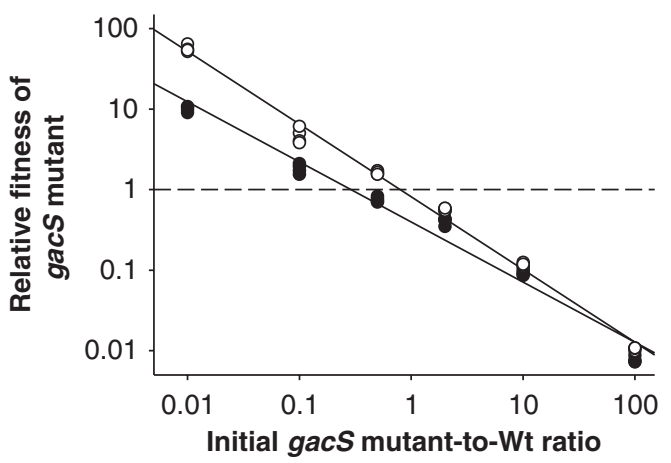

Figure 1 Relative fitness of the gacS mutant of Pseudomonas fluorescens CHA0 in the batch experiment after $48 \mathrm{~h}$ as a function of its initial frequency (initial gacS mutant-to-wild-type ratio) in the presence (black circles) or absence (open circles) of the predator Acanthamoeba castellanii. The relative fitness of the gacS mutant is expressed as ratio between its final and initial frequency; the two strains are at equilibrium at a relative fitness of 1 .

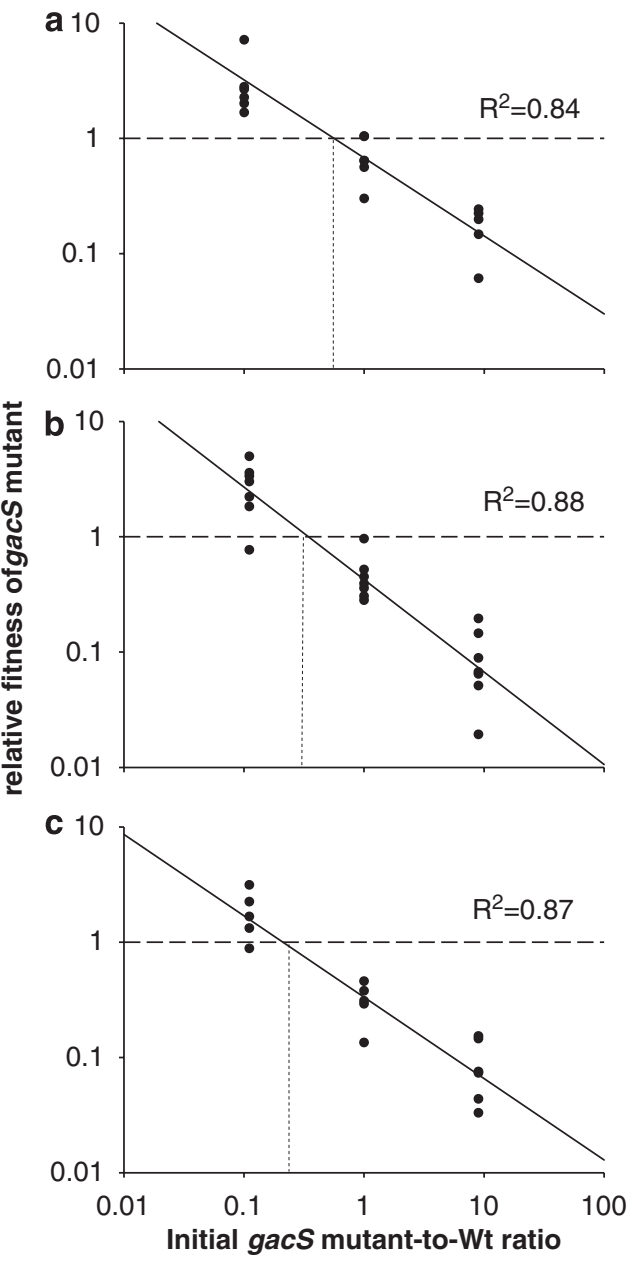

Figure 2 Relative fitness of the gacS mutant of Pseudomonas fluorescens CHAO in the rhizosphere of rice in relation to the initial gacS mutant-to-wild-type ratio without predators (a) with Caenorhabditis elegans (b) or Acanthamoeba castellanii (c). The vertical dashed lines indicate the frequency at which both strains are at equilibrium. 


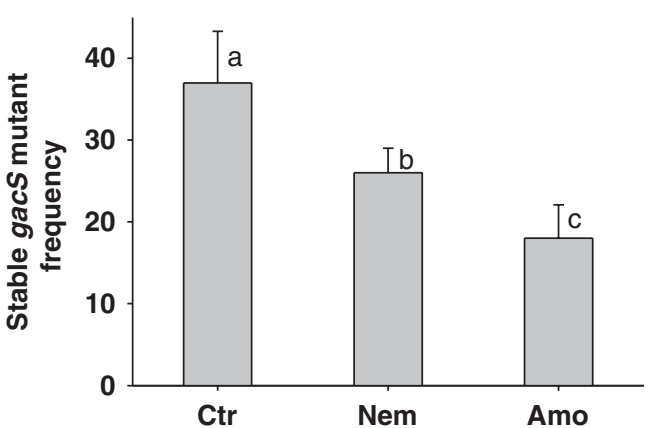

Figure 3 Predicted frequency at which the wild-type and GacS mutants of Pseudomonas fluorescens CHA0 are at equilibrium in bacterial populations without predator (Ctr), with Caenorhabditis elegans (Nem) or Acanthamoeba castellanii (Amo). Error bars indicate \pm s.e. $(N=6)$ for the intercept of the regression slopes (see Figure 2); different letters indicate significant differences between the intercept of the regression slopes (Tukey's HSD test, $\alpha=0.05$ ).

$35 \%$, where both strains were at equilibrium $(v=1)$. Amoebae rapidly reduced the fitness of the mutant strain (see Supplementary Figure S2), especially at low mutant frequency $\left(\mathrm{F}_{1,44}=34.7, P<0.001\right.$ for the interaction between predator and mutant frequency; Figure 1), suggesting food preference for the non-toxic strain. Predators thus shifted the relationship between frequency and relative fitness of the gacS mutant, reducing its equilibrium frequency to only $20 \%\left(\mathrm{~F}_{1,44}=6.37, P=0.015\right)$. Similar shifts occurred in the rhizosphere (Figure 2); likewise the fitness of the gacS mutant was negatively correlated with its initial frequency $\left(\mathrm{F}_{2,49}=295.4, P<0.001\right)$. Both predators reduced the fitness of the gacS mutant strain. They significantly shifted the intercept of the regression lines between gacS mutant frequency and relative fitness lowering the equilibrium mutant frequency from $37 \%$ in the control treatment to $26 \%$ and $18 \%$ in the nematode and amoebae treatments, respectively $\left(F_{2,49}=7.2, P=0.0015\right.$, Figure 3$)$. Linear regressions explained well the observed changes in mutant frequency $\left(r^{2}=0.84,0.88\right.$ and $0.87, P<0.001$ for control, nematode and amoeba treatments, respectively).

\section{Prey selection}

Both predators preferentially consumed gacS mutants in the rhizosphere, with preferences being more pronounced at low mutant frequency $\left(\mathrm{F}_{2,32}=9.5, P=0.001\right)$, suggesting active food selection. However, food selectivity strongly differed between predators $\left(\mathrm{F}_{1,32}=4.2, P=0.025\right)$. The nematodes were less selective (Figure 4), and their diet composition was only marginally influenced by the frequency of the two bacterial strains. In contrast, prey selection of amoebae decreased parallel to the increase in mutant frequency. The preference index indicates that amoebae preferentially consumed the mutant strain when present at low frequency $(s=2.4)$, but discriminated little between bacterial strains at the initial mutant frequency of $90 \%$ $(s=1.16$, Figure 5).

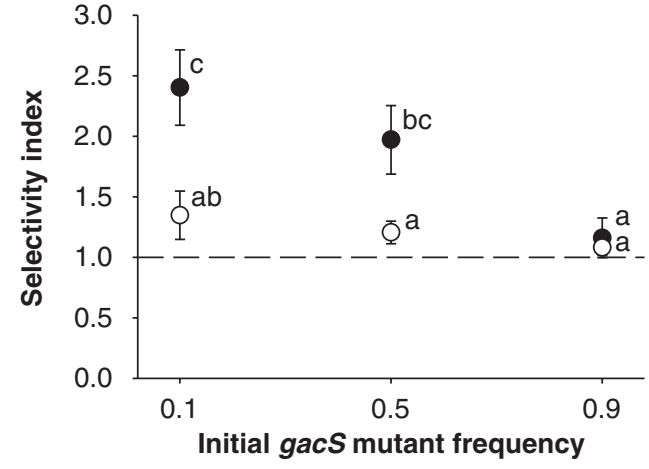

Figure 4 Food selectivity of Acanthamoeba castellanii (black circles) and Caenorhabditis elegans (white circles) at different frequencies of gacS mutants of Pseudomonas fluorescens CHA0. Values above 1 indicate preference for gacS mutants. Error bars indicate \pm s.e.; different letters indicate significant differences between means at $P<0.05$ (Tukey's HSD test).

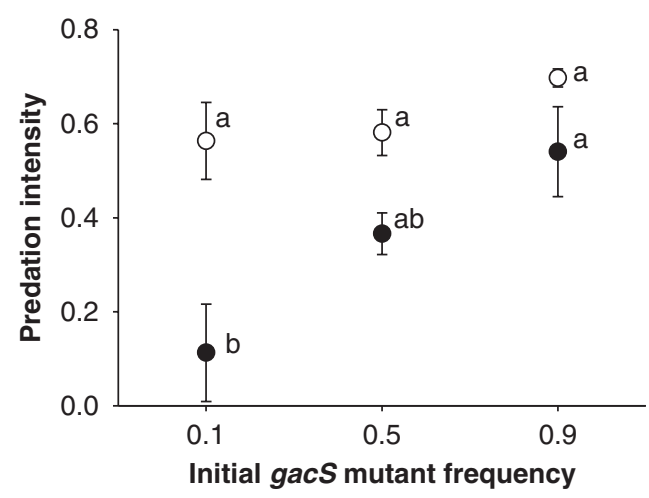

Figure 5 Predation intensity on the total bacterial population by Acanthamoeba castellanii (black circles) and Caenorhabditis elegans (white circles) at different initial frequencies of gacS mutants of Pseudomonas fluorescens CHA0. Predation intensity is expressed as percentage reduction in bacterial numbers compared with the respective treatment without predators at the end of the experiment. Error bars indicate \pm s.e.; different letters indicate significant differences between means at $P<0.05$ (Tukey's HSD test).

\section{Predation intensity}

In the absence of predators bacteria reached in the rhizosphere, an average total density of $5.5 \times 10^{6}$ cells (root system) ${ }^{-1}$ irrespective of the initial mutant frequency $\left(\mathrm{F}_{2,48}=1.14, P=0.328\right)$, suggesting that the carrying capacity of the system was independent of the initial mutant frequency. Nematodes and amoebae strongly reduced total bacterial numbers at the end of the experiment $\left(\mathrm{F}_{2,48}=24.4\right.$, $P<0.001$ ), with the effect of nematodes exceeding that of amoebae. Increasing gacS mutant frequency differently affected the predation pressure of the two predators $\left(\mathrm{F}_{2,32}=3.7, P=0.035\right.$ for the interaction between predator type and initial mutant frequency). Nematodes grazed on bacterial populations at all densities, thereby reducing bacterial numbers by $56 \%, 58 \%$ and $69 \%$ in $10 \%, 50 \%$ and $90 \%$ mutant treatments. In contrast, predation by amoebae 
increased with the frequency of gacS mutants, reducing bacterial numbers by $11 \%, 36 \%$ and $56 \%$ in $10 \%, 50 \%$ and $90 \%$ mutant treatments (Figure 5 ). This suggests that bacterial toxins efficiently protected the population against amoebae, but less against nematodes. Increasing mutant frequency resulted in a loss of this protection, confirming that the gacS mutant did not contribute to defence at the population level.

\section{Predator response}

The density of amoebae at the end of the experiment was independent of the initial frequency of gacS mutants and reached on average $1.34 \pm 0.89 \times 10^{4}$ individuals per $g$ sand $\left(F_{2,16}=0.40, P=0.700\right)$, suggesting low mortality even at high frequency of toxic bacteria, although more amoebae may have been encysted due to increased toxin concentrations. In contrast, nematode density tended to increase with initial mutant frequency $\left(\mathrm{F}_{2,16}=2.90\right.$, $P=0.082$ ), with actively swimming nematode numbers of 2.9, 4.5 and 6.5 individuals per $g$ sand in $10 \%, 50 \%$ and $90 \%$ mutant treatments, respectively, suggesting an inhibitory effect of the toxic wild-type bacteria on nematodes.

\section{Discussion}

Frequency-dependent fitness of gacS mutant bacteria Our results show that spontaneous gacS mutation in rhizosphere bacteria is an effective strategy to increase fitness by exploiting secondary metabolism of wild-type neighbours. Both in batch and rhizosphere systems, the fitness of gacS-deficient mutants proved to be negatively frequency dependent. This suggests that mutant bacteria are favoured within the wild-type populations, where they may contribute up to $40 \%$ of the population.

In microorganisms, the coordinated production of common goods, such as siderophores (Ross-Gillespie et al., 2007), extracellular enzymes (Greig and Travisano, 2004) or multicellular structures (Velicer et al., 2000), may strongly improve bacterial fitness, but is vulnerable to cheating. Typically, signal blind mutants rapidly evolve inside cooperating populations (Sandoz et al., 2007), reaping the benefits of the shared trait while sparing the associated costs. Cell signalling in $P$. fluorescens coordinates the production of exoproducts such as enzymes and toxins (Haas and Keel, 2003). Extracellular proteases, chitinases and lipases (van den Broek et al., 2003) contribute to the breakdown and assimilation of organic material. Moreover, our results show that secondary metabolites protect bacteria from predation (A. castellanii) or significantly reduce the fitness of the predators (C. elegans). Secondary metabolites, including enzymes and toxins, therefore, can be considered as a common good beneficial to the whole population.
The negative frequency-dependent fitness of the gacS mutant suggests that this strain exploits the exoproducts of the wild-type strain. Cell signalingdeficient mutants indeed may have higher maximum growth rates, but in pure culture reach lower density than the wild-type strain, lack extracellular enzymes such as phospholipases or proteases (Sacherer et al., 1994) and are more vulnerable to predation. However, the latter is not true in dense wild-type populations, indicating that the benefits of exploiting the exoproducts of neighbouring cells may outweigh the disadvantage of the altered phenotype.

Interestingly, a range of random and spontaneous mutations in the gacS/gacA genes, such as deletions, insertions and inversions, frequently switch off the response to population density signals (Martinez-Granero et al., 2005; van den Broek et al., 2005a). We propose that these high mutation rates result from the advantage of individual bacteria switching of cell signalling first. As the fitness of signal blind mutants depends on the frequency of wild-type bacteria, mutants evolving inside of an otherwise wild-type population receive greater benefit than bacteria mutating later when the relative frequency of wild-type bacteria has decreased. Remarkably, most mutations are reversible and cell signalling can be restored later (van den Broek et al., 2005b), suggesting increased fitness when reverting to the original phenotype in populations loaded with mutants.

\section{Selective feeding on gacS mutant bacteria}

Predation exerts a major selective pressure on free living bacteria (Pernthaler, 2005) and plays a key role in driving bacterial microevolution (Wildschutte et al., 2004; Meyer and Kassen, 2007). Consequently, bacteria evolved sophisticated defence strategies, including the production of toxins that repel or inhibit their predators (Andersen and Winding, 2004; Matz et al., 2004; Jousset et al., 2006). The production of these toxins often is density dependent resulting in increased protection of related neighbouring cells (Matz and Kjelleberg, 2005).

Both predators preferentially consumed gacS mutant bacteria, documenting that amoebae and nematodes can select their prey and that extracellular toxins act as repellent. Prey selection is crucial for bacterivores, such as protozoa and nematodes, as the quality of ingested bacteria directly affects their fitness (Zubkov and Sleigh, 2000; Blanc et al., 2006; Jousset et al., 2006). In particular, amoebae were highly selective and preferentially consumed the non-toxic mutant in both the batch and rhizosphere experiment. Despite being less selective, nematodes also negatively affected the gacS-deficient mutant. Grazing by nematodes reduced total bacterial density, and thereby decreasing the size of the wild-type population. As the production of secondary meta- 
bolites is density dependent, this likely impairs the protection of the mutant strain. Generally, the results confirm the vulnerability of gacS mutant bacteria to predation and support our hypotheses that they gain protection by toxins from wild-type bacteria.

\section{Predation and population level defence}

Predation was markedly reduced in populations with low gacS mutant frequency, suggesting that in addition to the individual level, bacteria benefit from the dominance of wild-type bacteria at the population level. Vulnerability to predation at high mutant frequency is in agreement with past observations that the biocontrol function of P. fluorescens collapses with increasing frequencies of gacS mutants (Duffy and Defago, 2000). The gacS mutant bacteria produce neither toxins nor autoinducers (Lapouge et al., 2008), thus interfering with toxin production of wild-type bacteria. Consequently, proliferation of the mutant compromises the population level traits from which this strain benefits. If bacterial populations become overloaded with mutants, as is the case in the presence of hypermutable strains (Harrison and Buckling, 2005), the whole population may be eliminated by predators, suggesting that in spatially structured habitats predation may enforce cooperation, that is, toxin production, at the group level by counter selecting defenceless populations. Overall, toxin-mediated attenuation of predation by wild-type bacteria may help explain why keeping the ability to produce secondary metabolites in P. fluorescens is evolutionary stable despite the associated costs and the frequent loss of this function.

\section{Conclusions}

Results of this study suggest that by selectively feeding on non-toxic bacteria and reducing predation on bacterial populations loaded with mutants, predators reinforce toxin production of wild-type bacteria at both the individual and population levels. The study, therefore, provides an ecological and evolutionary explanation for the spontaneous deactivation of cell signalling by pseudomonads. At low frequency, signal blind toxin-deficient mutants profit from the exoproducts of coexisting wild-type bacteria, suggesting that they improve their fitness by cheating. Predators, especially amoebae, reduced the frequency of non-toxic phenotypes than nematodes, suggesting that protozoa efficiently reinforce toxicity of bacterial communities. Intriguing bacterial traits, such as the spontaneous deactivation of the GacS/GacA-mediated toxin production in pseudomonads, likely evolved in the context of predation pressure. Predator-prey interactions, therefore, not only allow a mechanistic understanding of the factors driving population dynamics and evolution of cooperating and cheating in Pseudomonas strains but also may allow developing strategies for the successful establishment of biocontrol bacteria in the rhizosphere of plants.

\section{Acknowledgements}

We are grateful to Dirk Bumann (University of Basel, Switzerland) for providing the DsRed variant vector pDsRed.T3_S4T and Eric Baehler for his preparatory work on the DsRed fusion used in this study. We thank Ulrich Brose (Darmstadt University of Technology, Germany) for advice on modelling. Further, we thank Bryan Griffiths (Teagasc Environment Research Centre, Ireland) for providing nematode cultures, René Erdmann (Darmstadt University of Technology, Germany) for culturing them axenically, Katja Rosenberg (Darmstadt University of Technology, Germany) for providing axenic amoebae cultures and Xin Ke (Chinese Academy of Agricultural Sciences, China) for providing the rice seeds. This study was funded by the fellowship programme of the German Federal Foundation for the Environment (DBU) and by the Swiss National Science Foundation (project 3100A0105881).

\section{References}

Andersen KS, Winding A. (2004). Non-target effect of bacterial biological control agents on soil protozoa. Biol Fertil Soils 40: 230-236.

Baehler E, De Werra P, Wick LY, Pechy-Tarr M, Mathys S, Maurhofer $\mathrm{M}$ et al. (2006). Two novel Mvat-like global regulators control exoproduct formation and biocontrol activity in root-associated Pseudomonas fluorescens CHA0. Mol Plant-Microbe Interact 19: 313-329.

Bao Y, Lies DP, Fu H, Roberts GP. (1991). An improved Tn7-based system for the single-copy insertion of cloned genes into chromosomes of gram-negative bacteria. Gene 109: 167-168.

Blanc C, Sy M, Djigal D, Brauman A, Normand P, Villenave C. (2006). Nutrition on bacteria by bacterial-feeding nematodes and consequences on the structure of soil bacterial community. Eur J Soil Biol 42: S70-S78.

Bonkowski M, Brandt F. (2002). Do soil protozoa enhance plant growth by hormonal effects? Soil Biol Biochem 34: 1709-1715.

Bull CT, Duffy B, Voisard C, Defago G, Keel C, Haas D. (2001). Characterization of spontaneous gacS and gacA regulatory mutants of Pseudomonas fluorescens biocontrol strain CHAO. Antonie van Leeuwenhoek 79: $327-336$.

Chancey ST, Wood DW, Pierson EA, Pierson LSI. (2002). Survival of GacS/GacA mutants of the biological control bacterium Pseudomonas aureofaciens 30-84 in the wheat rhizosphere. Appl Environ Microbiol 68: 3308-3314.

Darbyshire JF, Wheatley RE, Greaves MP, Inkson RHE. (1974). Rapid micromethod for estimating bacterial and protozoan populations in soil. Eur J Soil Biol 11: $465-475$.

de Werra P, Baehler E, Huser A, Keel C, Maurhofer M. (2008). Detection of plant-modulated alterations in antifungal gene expression in Pseudomonas fluores- 
cens CHA0 on roots by flow cytometry. Appl Environ Microbiol 74: 1339-1349.

Dubuis C, Haas D. (2007). Cross-species GacA-controlled induction of antibiosis in pseudomonads. Appl Environ Microbiol 73: 650-654.

Dubuis C, Keel C, Haas D. (2007). Dialogues of rootcolonizing biocontrol pseudomonads. Eur J Plant Pathol 119: 311-328.

Duffy BK, Defago G. (2000). Controlling instability in gacS-gacA regulatory genes during inoculant production of Pseudomonas fluorescens biocontrol strains. Appl Environ Microbiol 66: 3142-3150.

Greig D, Travisano M. (2004). The Prisoner's dilemma and polymorphism in yeast SUC genes. P Roy Soc B-Biol Sci 271: S25-S26.

Haas D, Defago G. (2005). Biological control of soil-borne pathogens by fluorescent pseudomonads. Nat Rev Microbiol 3: 307-319.

Haas D, Keel C. (2003). Regulation of antibiotic production in root-colonizing Pseudomonas spp. and relevance for biological control of plant disease. Annu Rev Phytopathol 41: 117-153.

Haas D, Keel C, Reimmann C. (2002). Signal transduction in plant-beneficial rhizobacteria with biocontrol properties. Antonie van Leeuwenhoek 81: 385-395.

Harrison F, Buckling A. (2005). Hypermutability impedes cooperation in pathogenic bacteria. Curr Biol 15: 1968-1971.

Hurek T, Reinholdhurek B, Vanmontagu M, Kellenberger E. (1994). Root colonization and systemic spreading of Azoarcus sp. strain BH72 in grasses. J Bacteriol 176: 1913-1923.

Jezbera J, Hornak K, Simek K. (2006). Prey selectivity of bacterivorous protists in different size fractions of reservoir water amended with nutrients. Environ Microbiol 8: 1330-1339.

Jousset A, Lara E, Wall LG, Valverde C. (2006). Secondary metabolites help biocontrol strain Pseudomonas fluorescens CHA0 to escape predation. Appl Environ Microbiol 72: 7083-7090.

Jousset A, Scheu S, Bonkowski M. (2008). Secondary metabolite production facilitates establishment of rhizobacteria by reducing both protozoan predation and the competitive effects of indigenous bacteria. Funct Ecol 22: 714-719.

Koch B, Jensen L, Nybroe O. (2001). A panel of Tn7-based vectors for insertion of the $g f p$ marker gene or for delivery of cloned DNA into Gram-negative bacteria at a neutral chromosomal site. J Microbiol Methods 45: 187-195.

Lapouge K, Schubert M, Allain FHT, Haas D. (2008). Gac/ Rsm signal transduction pathway of gamma-proteobacteria: from RNA recognition to regulation of social behaviour. Mol Microbiol 67: 241-253.

Liu XY, Shi M, Liao YH, Gao Y, Zhang ZK, Wen DH et al. (2006). Feeding characteristics of an amoeba (Lobosea: Naegleria) grazing upon cyanobacteria: food selection, ingestion and digestion progress. Microb Ecol 51: $315-325$

Martinez-Granero F, Capdevila S, Sanchez-Contreras M, Martin M, Rivilla R. (2005). Two site-specific recombinases are implicated in phenotypic variation and competitive rhizosphere colonization in Pseudomonas fluorescens. Microbiology 151: 975-983.

Matz C, Deines P, Boenigk J, Arndt H, Eberl L, Kjelleberg S et al. (2004). Impact of violacein-producing bacteria on survival and feeding of bacterivorous nanoflagellates. Appl Environ Microbiol 70: 1593-1599.

Matz C, Kjelleberg S. (2005). Off the hook-how bacteria survive protozoan grazing. Trends Microbiol 13: 302-307.

Meyer JR, Kassen R. (2007). The effects of competition and predation on diversification in a model adaptive radiation. Nature 446: 432-435.

Natsch A, Keel C, Pfirter HA, Haas D, Defago G. (1994). Contribution of the global regulator gene gacA to persistence and dissemination of Pseudomonas fluorescens biocontrol strain CHA0 introduced into soil microcosms. Appl Environ Microbiol 60: 2553-2560.

Page FC. (1988). A New Key to Freshwater and Soil Gymnaboeae. Freshwater Biological Association: Ambleside.

Pernthaler J. (2005). Predation on prokaryotes in the water column and its ecological implications. Nat Rev Microbiol 3: 537-546.

Rønn R, McCaig A, Griffiths B, Prosser J. (2002). Impact of protozoan grazing on bacterial community structure in soil microcosms. Appl Environ Microbiol 68: 6094-6105.

Ross-Gillespie A, Gardner A, West SA, Griffin AS. (2007). Frequency dependence and cooperation: theory and a test with bacteria. Am Nat 170: 331-342.

Sacherer P, Defago G, Haas D. (1994). Extracellular protease and phospholipase-C are controlled by the global regulatory gene gacA in the biocontrol strain Pseudomonas fluorescens CHA0. FEMS Microbiol Lett 116: $155-160$.

Sanchez-Contreras M, Martín M, Villacieros M, O’Gara F, Bonilla I, Rivilla R. (2002). Phenotypic selection and phase variation occur during alfalfa root colonization by Pseudomonas fluorescens F113. J Bacteriol 184: 1587-1596.

Sandoz KM, Mitzimberg SM, Schuster M. (2007). Social cheating in Pseudomonas aeruginosa quorum sensing. Proc Natl Acad Sci USA 104: 15876-15881.

Sorensen M, Lippuner C, Kaiser T, Misslitz A, Aebischer T, Bumann D. (2003). Rapidly maturing red fluorescent protein variants with strongly enhanced brightness in bacteria. FEBS Lett 552: 110-114.

van den Broek D, Bloemberg GV, Lugtenberg B. (2005a). The role of phenotypic variation in rhizosphere Pseudomonas bacteria. Environ Microbiol 7: 1686-1697.

van den Broek D, Chin-a-Woeng TFC, Bloemberg GV, Lugtenberg BJJ. (2005b). Molecular nature of spontaneous modifications in GacS which cause colony phase variation in Pseudomonas sp. Strain PCL1171. J Bacteriol 187: 593-600.

van den Broek D, Chin-a-Woeng TFC, Eijkemans K, Mulders IHM, Bloemberg GV, Lugtenberg BJJ. (2003). Biocontrol traits of Pseudomonas spp. are regulated by phase variation. Mol Plant Microbe Interact 16: 1003-1012.

Velicer GJ, Kroos L, Lenski RE. (2000). Developmental cheating in the social bacterium Myхососcus xanthus. Nature 404: 598-601.

Voisard C, Bull CT, Keel C, Laville J, Maurhofer M, Schnider M. (1994). Biocontrol of root diseases by Pseudomonas fluorescens CHA0: current concepts and experimental approaches. In: O'Gara F, Dowling DN, Boesten B (eds). Molecular Ecology of Rhizosphere Microorganisms. VCH Verlagsgesellschaft mbH: Weinheim, Germany. pp 67-89. 
Walia H, Wilson C, Condamine P, Liu X, Ismail AM, Zeng LH et al. (2005). Comparative transcriptional profiling of two contrasting rice genotypes under salinity stress during the vegetative growth stage. Plant Physiol 139: 822-835.

Weitere M, Bergfeld T, Rice SA, Matz C, Kjelleberg S. (2005). Grazing resistance of Pseudomonas aeruginosa biofilms depends on type of protective mechanism, developmental stage and protozoan feeding mode. Environ Microbiol 7: 1593-1601.

Wildschutte H, Wolfe DM, Tamewitz A, Lawrence JG. (2004). Protozoan predation, diversifying selection, and the evolution of antigenic diversity in Salmonella. Proc Natl Acad Sci USA 101: 10644-10649.

Zuber S, Carruthers F, Keel C, Mattart A, Blumer C, Pessi G et al. (2003). GacS sensor domains pertinent to the regulation of exoproduct formation and to the biocontrol potential of Pseudomonas fluorescens CHA0. Mol Plant Microbe Interact 16: 634-644.

Zubkov MV, Sleigh MA. (2000). Comparison of growth efficiencies of protozoa growing on bacteria deposited on surfaces and in suspension. J Eukaryot Microbiol 47: $62-69$.

Supplementary Information accompanies the paper on The ISME Journal website (http://www.nature.com/ismej) 